\title{
0 chamado à decisão entre o conhecimento da vontade de Deus e o arrependimento na teologia escatológico-existencial de Bultmann
}

\author{
The call to decision between knowledge of God's will \\ and repentance in the eschatological-existential \\ theology of Bultmann
}

\section{La llamada a la decisión entre conocer la voluntad de Dios y el arrepentimiento en la teología escatológico- existencial de Bultmann}

Luiz Carlos Mariano da Rosa

\begin{abstract}
RESUMO
Se a pregação de Jesus consiste no pressuposto da teologia neotestamentária, segundo o pensamento de Bultmann, a análise do seu conteúdo emerge como fundamental para a compreensão do querigma cristão e da construção literário-teológica da comunidade primitiva. Dessa forma, o artigo se detém na pregação ético-escatológica de Jesus, que anuncia o reino de Deus e o tempo da decisão e o chamado à decisão, que converge para a radicalidade e exige a obediência escatológica enquanto realização da vontade de Deus. Assim, escapando à condição de um dever que converge para a formação do caráter e ao princípio de determinação da comunhão humana, o artigo assinala que é a exigência do amor que se impõe à pregação escatológica de Jesus e a sua pregação ética e ao conhecimento da vontade de Deus, que implica o dever-ser e o poder-fazer envolvendo o bem incondicional em uma construção teórico-conceitual e subjetivo-existencial que envolve a consciência da situação-limite da existência e a necessidade de uma decisão existencial.

Palavras-chave: Bultmann; reino de Deus; obediência escatológica; pregação ético-escatológica; teologia escatológico-existencial.
\end{abstract}

\footnotetext{
ABSTRACT

If the preaching of Jesus consists of the assumption of New Testament theology, according to Bultmann's thought, the analysis of its content emerges as fundamental for the understanding of the Christian kerygma and the literary-theological construction of the primitive community. In this way, the article focuses on Jesus' ethical-eschatological preaching, which announces the kingdom of God and the time of decision and the call for decision, which converges to radicality and demands eschatological obedience as the fulfillment of God's will. Thus, escaping the condition of a duty that converges to the formation of character and the principle of determination of human communion, the article points out that it is the demand for love that imposes itself on Jesus' eschatological preaching and his ethical preaching and the knowledge of God's will, which implies the must-be and the can-do involving unconditional good in a theoretical-conceptual and subjective-existential construction that involves awareness of the limit situation of existence and the need for an existential decision. Keywords: Bultmann; God's kingdom; eschatological obedience; ethical-eschatological preaching; eschatological-existential theology.
} 


\begin{abstract}
RESUMEN
Si la predicación de Jesús consiste en la asunción de la teología neotestamentaria, según el pensamiento de Bultmann, el análisis de su contenido surge como fundamental para la comprensión del kerigma cristiano y la construcción literario-teológica de la comunidad primitiva. De esta manera, el artículo se centra en la predicación ético-escatológica de Jesús, que anuncia el reino de Dios y el momento de la decisión y la llamada a la decisión, que confluye en la radicalidad y exige la obediencia escatológica como cumplimiento de la voluntad de Dios. Así, escapando de la condición de deber que confluye a la formación del carácter y al principio determinante de la comunión humana, el artículo señala que es la exigencia de amor la que se impone a la predicación escatológica y a su predicación ética y al conocimiento de Jesús. La voluntad de Dios, que implica el deber-ser y el poder-hacer involucrando el bien incondicional en una construcción teórico-conceptual y subjetivo-existencial que involucra la conciencia de la situación límite de la existencia y la necesidad de una decisión existencial. Palabras clave: Bultmann; reino de Dios; obediencia escatológica; predicación ético-escatológica; teología escatológico-existencial.
\end{abstract}

\title{
Introdução
}

Encerrando a proclamação de Jesus Cristo, o crucificado e ressurreto, como ato salvífico escatológico de Deus, o querigma (kerygma) ${ }^{1}$ funda a fé cristã em um processo que converge para uma construção teológica que guarda correspondência com o conteúdo elaborado pela experiência da reflexão instaurada pela comunidade primitiva em função do seu objeto, do seu fundamento e das suas consequências. Dessa forma, se a pregação de Jesus de Nazaré consiste no pressuposto da teologia neotestamentária, segundo o pensamento de Bultmann, a análise do seu conteúdo emerge como fundamental para a compreensão do querigma cristão e da construção literário-teológica da comunidade primitiva.

Nesta perspectiva, o presente artigo se detém no caráter ético-escatológico da mensagem de Jesus que, assinalando como conceito fundamental

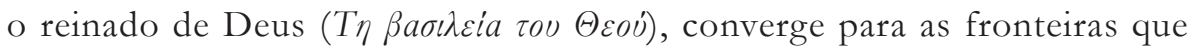
envolvem o término do atual curso do mundo e do presente tempo através da irrupção do reino de Deus ${ }^{2}$ enquanto governo de Deus, cuja manifestação, iminente, implica o acontecimento maravilhoso que encerra o fim de todo sofrimento e dor e que, dependendo inteiramente de Deus, concorre para a salvação do povo de Deus.

1 "O elemento central da pregação era a mensagem de que, apesar de ter sido crucificado, Cristo ressuscitou dentre os mortos, esse é o kêrygma (o conteńdo daquilo que era proclamado: I Co 15.14)." (VANGEMEREN, 2011, p. 752, grifo do autor)

2 Dessa forma, cabe salientar que "a concepção popular do reino dos céus, como um mundo celestial sobre o firmamento, no qual os piedosos ingressarão após a morte, não se encontra no NT, mas nos apocalipses judaicos e, de forma diferente, na gnose. Jesus pode ter usado paralelamente, com o mesmo sentido, 'reino de Deus' e 'reino dos céus'. Por outro lado, as fórmulas encontradas ocasionalmente, 'reino do Pai', 'o reino' (absoluto) ou 'reino do filho do homem' são formulações cristãs secundárias. A locução 'reino de Deus' provém de Jesus, pois fora dos evangelhos sinóticos quase que inexiste no NT". (GOPPELT, 2002, p. 81) 
Tendo como fundamento teórico-conceitual o reinado de Deus, a pregação de Jesus se sobrepõe ao caráter nacionalista da expectativa judaica em relação à restauração do reino davídico, na medida em que, segundo a perspectiva de Bultmann, guarda correspondência com a literatura apocalíptica em uma construção que dialoga com a ideia envolvendo o fim das condições do atual curso do mundo, encerrando uma concepção dualista-pessimista da sua corrupção satânica que converge para as fronteiras que assinalam a irrupção do novo éon por intermédio do fim do velho éon sob a égide de terror e sofrimento.

Nesta perspectiva, longe de atribuir ao reino de Deus a condição de uma grandeza passível de evolução histórica enquanto processo cuja instauração guarda correspondência com a necessidade de intervenção humana, Jesus em sua pregação assinala, de acordo com a teologia escatológico-existencial de Bultmann, a absoluta independência do reinado de Deus em face de qualquer tipo de contributo humano acerca do seu progresso, convergindo para um anúncio que encerra o tempo da decisão e implica o chamado à decisão, na medida em que em Sua pessoa Jesus consiste no sinal do tempo e a exigência diante de tal condição de irrupção do reino de Deus envolve um "estar de prontidão" ou um "preparar-se" enquanto obediência escatológica como realização da vontade de Deus.

Dessa forma, baseada na noção que envolve o tempo do fim, Jesus em sua pregação do reino de Deus chama à decisão em uma construção que, segundo o pensamento de Bultmann, converge para a radicalidade e implica a escolha entre Deus ou o mundo enquanto negação de si como condição para o ser humano tornar-se discípulo em um processo que encerra a incompatibilidade fundamental entre Deus e o seu reinado e o mundo e os seus bens.

Assim sendo, transpondo as fronteiras que envolvem a condição de um dever que implica a formação do caráter, como também ao princípio de determinação da comunhão humana, o artigo assinala que, de acordo com a teologia escatológico-existencial de Bultmann, é a exigência do amor que se impõe à pregação ético-escatológica de Jesus e consiste no cumprimento da vontade de Deus em um processo que guarda correspondência com a noção de que a participação na sua salvação encerra imperativos que se sobrepõem ao sentido de mandamentos de exceção e constituem um conteúdo que carrega a radicalidade de uma exigência absoluta.

\section{Do caráter escatológico-existencial do reino de Deus enquanto governo de Deus e o chamado à decisão como negação de si}

"Ao anunciar a vinda do reino, Jesus não introduz um termo novo. Não anuncia a existência de um reino de Deus, mas o fato de que ele agora vem" (GOPPELT, 2002, p. 81, grifos do autor). Consistindo em um conceito escato- 
lógico, o reinado de Deus guarda correspondência com a noção que envolve o governo de Deus em uma construção que implica o fim do atual curso do mundo, perfazendo uma manifestação que acarreta a destruição de tudo quanto se opõe a Deus em um processo que elimina o sofrimento e a dor em sua totalidade e institui a salvação para o povo de Deus, convergindo para as fronteiras que encerram uma irrupção de modo imediato e caráter iminente que depende unicamente da iniciativa de Deus ${ }^{3}$. Dessa forma, sobrepondo-se a condição de bem-estar e glória em seu caráter nacionalista, a salvação dos justos implica uma vida paradisíaca, convergindo para um estado de bem-

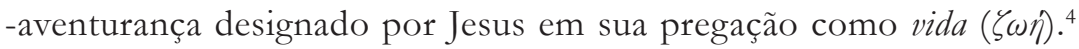

Se a pregação de Jesus traz como base teórico-conceitual o reinado de Deus em uma construção que implica correspondência em face do contexto histórico-cultural judaico e a sua expectativa em relação ao fim e ao futuro, não há qualquer liame envolvendo a Sua mensagem e o nacionalismo que caracteriza a esperança judaica concernente à restauração do reino davídico através de um processo de transfiguração instaurado sob a égide de um ideal, ${ }^{5}$ na medida em que Jesus não se detém em sua palavra na imagem do messias-rei e no exercício

\footnotetext{
"Em nenhum lugar da mensagem de Jesus a basileia designa o reino perpétuo de Deus sobre Israel na presente era. (A ideia está de fato presente em Mt 21,43: arthésetai aph'bymôn be basileía toû Theồ, mas o versículo não se acha em Marcos e é, portanto, uma adição). Antes, a basileia sempre e em todo lugar se entende escatologicamente; designa o tempo da salvação, a consumação do mundo, a reconstituição da comunhão de vida que fora destruída entre Deus e o homem. Jesus retoma aí especialmente Dn 2,44, segundo o qual o Deus dos céus estabelecerá uma soberania eterna, e Dn 7,27, segundo o qual se dará ao povo dos santos do Altíssimo o reino (cf. Lc 12,32), como também sob outros aspectos o livro de Daniel lhe é sobremodo importante. Quando, pois, Jesus anuncia e faz os discípulos anunciarem éggiken he basileía tồ Theồ (Mc 1,15 par. Mt 4,17;10,7; Lc 10,9,11), significa: está perto a hora escatológica de Deus, a vitória de Deus, a consumação do mundo." (JEREMIAS, 1977, p. 159).

4 "O sentido propriamente dito da promissão do vindouro reino de Deus só poderá ser reconhecido caso perguntarmos pelos termos paralelos com os quais Jesus descreve a salvação do reino de Deus. Dentre eles sobressai o termo 'vida eterna'. Assim como Jesus fala de 'entrar no reino de Deus' também se expressa a respeito de 'entrar na vida' (Mc 9.43,45,47 par.). Tal como fala de herdar o 'reino de Deus', igualmente menciona a 'herança da vida' (Mt 25.34; Mc 10.17 par.). Consequentemente Jesus pretende mostrar o 'caminho que conduz para a vida' (Mt 7.14). Além disso, 'entrar na vida' corresponde ao 'entrar no gozo' (Mt 25.21,23), à 'participação na glória' (Mc 10.37) e à 'participação na luz' (Lc 16.8). Todas essas figuras descrevem a mesma realidade, qual seja, aquele que tem direito a entrar no reino de Deus prestes a irromper poderá participar na vida e na glória de Deus e será recebido na casa paterna (Lc 15.24,31)." (KÜMMEL, 2003, p. 55).

5 "Quando do exílio, é particularmente Ezequiel quem confere ao futuro rei os traços precisos que caracterizarão, doravante, a figura do Messias. Segundo Ez 37.21 ss., o dia virá em que o reino de Israel inteiro será unido sob o cetro de Davi, e este reinará eternamente. Porém, a esperança da vinda de um rei da casa de Davi no fim dos tempos assumiu suas formas mais vivas posteriormente, quando, sob a dominação grega, o nacionalismo judaico alcançara seu desenvolvimento máximo. Esperava-se então um rei totalmente terreno, político, e não um ser celestial que apareceria sobre a terra de uma forma milagrosa. Segundo uns, por exemplo o redator da profecia de Zacarias 9.9 s., seria, antes, um rei pacífico, o qual não estaria impedido de desempenhar um papel essencialmente político. Para outros, muito numerosos, haveria de ser um soberano belicoso cuja primeira preocupação seria a de vencer todos os inimigos de Israel. É assim que aparece em particular nos Salmos de Salomão. Nos Salmos 17 e 18 deste

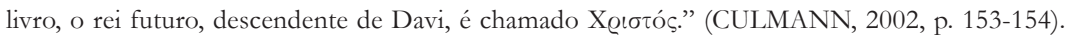


do seu poder sobre os inimigos, nem tampouco no domínio de Israel sobre a terra e na promessa de felicidade e paz no referido país, tendo em vista que a perspectiva de Jesus traz como fundamento a literatura apocalíptica e a expectativa de um evento capaz de produzir o fim das condições do atual curso do mundo, a saber, uma catástrofe cósmica.

Que pretende Jesus dizer ao anunciar a iminente vinda do reino de Deus? A esperança de Israel desde a época do exílio babilônico consistia em que, no futuro, Deus edificaria o seu senhorio na condição de rei sobre o seu povo de Israel de uma maneira tal que seria visível a todos os povos do mundo. O judeu piedoso da época de Jesus orava diariamente o seguinte “Tu somente, Senhor, sejas rei sobre nós!”. Naturalmente o judeu também estava ciente de que já agora Deus é rei, podendo, por essa razão, invocá-lo como “nosso Pai, nosso Rei”. Contudo o reinado de Deus permanece oculto no presente e, por isso, se espera pela iminente manifestação desse reinado. (KÜMMEL, 2003, p. 54).

Dessa forma, sobrepondo-se à esperança que implica a expectativa envolvendo a transformação das condições históricas, políticas e sociais, a expectativa que encerra a pregação de Jesus guarda a pressuposição da concepção dualista-pessimista da corrupção satânica do mundo em sua totalidade, convergindo para as fronteiras que envolvem a construção teórico-conceitual que afirma a existência de dois éones em relação ao movimento do mundo em um processo que assinala a irrupção do novo éon por intermédio do fim do velho éon sob a égide de terror e sofrimento.

Baseado na certeza de que o velho éon havia chegado ao fim, Jesus afirma a chegada do reino de Deus ${ }^{6}$, assinalando que, se Satanás e seus demônios mantém sob domínio e controle o atual curso do mundo, o tempo passou e o que se impõe é a expectativa da manifestação do "Filho do homem" em sua vinda como juiz e salvador em um processo que implica a ressurreição dos mortos e o juízo, que envolve condenação no inferno de fogo, constituindo-se a ceia celestial ${ }^{7}$ o evento que reunirá à mesa com Abraão, Isaque e Jacó

${ }^{6}$ "Nos evangelhos, alternam-se be basileía tổ Theồ, 'o reino de Deus', e be basileía tôn ouranôn, 'o reino dos céus'. As duas expressões significam a mesma coisa, pois hoi ouranoí, 'os céus', é mera circunlocução para dizer Deus. Disputa-se ainda sobre qual teria sido a expressão usada por Jesus. Um ponto de referência para responder a esta questão é que o termo 'reino dos céus' aparece pela primeira vez na literatura judaica meio século depois do ministério de Jesus, com o rabi Yohanan ben Zakkai, cerca de 80 d.C. o total silêncio da literatura intertestamentária faz bastante improvável, se não totalmente impensável, que a expressão 'reino dos céus' tenha sido já linguagem corrente ao tempo de Jesus e tenha sido assumida por ele. Por outro lado, nada sugere que Jesus não tenha dito 'reino de Deus'." (JEREMIAS, 1977, p. 152).

7 "Digo-vos que muitos virão do Oriente e do Ocidente e tomarão lugares à mesa com Abraão, Isaque e Jacó no reino dos céus” (Mt. 8,11, p. 1112). O referido evento guarda correspondência com o tema do banquete messiânico, conteúdo do oráculo profético de Isaías (Is 25.6-9), que implica a paternidade abraâmica enquanto uma construção que se sobrepõe a descendência física e converge 
os escolhidos que, na ressurreição, assumirão uma condição equivalente aos anjos no céu, convergindo para uma construção apocalíptica do futuro que traz uma imagem de caráter reduzido cuja condição nova e própria guarda correspondência com a sua veemente defesa e absoluta convicção de que o reino de Deus está chegando. ${ }^{8}$

A função do profeta escatológico consiste acima de tudo, segundo os textos judaicos, em preparar por sua pregação o povo de Israel e o mundo para a vinda do Reino de Deus; e isto não à maneira dos profetas do Antigo Testamento, mas de um modo muito mais direto: como precursor imediato do advento deste Reino. Ele vem armado de uma autoridade escatológica que lhe é privativa. Seu chamado ao arrependimento é absoluto e exige uma decisão definitiva, o que dá à sua pregação um caráter final, absoluto, que nem mesmo a palavra dos antigos profetas possuía no mesmo grau. (CULLMANN, 2002, p. 67).

Constituindo-se os sinais dos tempos o Seu aparecimento, tanto quanto a Sua atuação, como também a Sua pregação, as profecias de salvação que Jesus transmite em seu discurso encerram realidades cuja concretização implica as próprias obras milagrosas que realiza no exercício de Sua missão através do poder de Deus ${ }^{9}$, a despeito de sua objeção

para as fronteiras que encerram parentesco espiritual e caráter universal. "A basileia entende-se também claramente em sentido escatológico nas metáforas associadas com o banquete salvífico, que dizem que o próprio Jesus (Mc 14,25), Abraão, Isaque e Jacó, e os profetas (Lc 13,28), bem como os pagãos afluindo de toda a rosa-dos-ventos (V. 29) se assentarão à mesa no "reino de Deus"” (JEREMIAS, 1977, p. 156-157).

8 "Para entender as palavras de Jesus referentes à basileia, é de grande importância saber quais as ideias que os homens do seu tempo ligavam à expressão 'reino de Deus'. Vimos que ela não era corrente no judaísmo pré-cristão. Nossa documentação é relativamente escassa, mesmo assumindo as passagens em que se aplicam o verbo malak e o nomo melek para Deus. É certo que a palavra malkuta não tem para o oriental o mesmo sentido que a palavra 'reino' para o ocidental. Pois só em muito poucos casos no Antigo Testamento malkut denota um reino no sentido espacial, um território; quase sempre quer dizer o poder de reinar, a autoridade, o poder dum rei. Mas não significa que malkut seja entendido abstratamente, mas, antes, está sempre em processo de realizar-se. Portanto, reino de Deus não é conceito espacial nem estático, mas dinâmico. Significa a soberania real de Deus em ação, primeiramente como oposta à soberania real humana, mas também a seguir como oposta a toda a soberania no céu e na terra. Sua marca principal é que Deus está realizando o ideal de justiça que sempre se esperava do rei, mas nunca realizado na terra." (JEREMIAS, 1977, p. 153-154).

9 “A pregação não é caracterizada apenas como profecia e anúncio, mas também como proclamação e promulgação. Isso é explicado primariamente pelo poder ou autoridade com a qual Jesus prega o evangelho do reino. Sua palavra não é apenas um sinal - ela está carregada de poder - e tem à sua disposição a substância, a salvação que ela própria define: não é somente uma palavra, mas 'fará o que apraz' àquele que a pronuncia. Esse é o motivo pelo qual, ao fim, não existe diferença entre a palavra com a qual Jesus expele os demônios e a sua pregação do evangelho. Em ambos os casos, a palavra e o que ela indica formam uma unidade. Em nenhum lugar essa conexão é vista tão claramente como na história da cura do paralítico (Mc 2.1-12 e paral.).” (RIDDERBOS, 2010, p. 72, grifos do autor). 
à utilização de "um sinal do céu" 10 para alcançar legitimação diante do povo judeu.

Se, "sob o ponto de vista histórico, a pregação do Batista se orientava na vinda do 'que há de vir'; a de Jesus, no entanto, se orientava na vinda de Deus, isto é, no seu domínio" (GOPPELT, 2002, p. 81), os sinais dos tempos, que no aparecimento de Jesus, na Sua atuação e pregação têm o seu cumprimento, assinalam que o reinado de Deus está chegando, não convergem, contudo, para a conclusão de que o reino de Deus já é presente, na medida em que, longe de consistir em uma grandeza que se desenvolve na história em um movimento passível de intervenção humana, perfaz uma manifestação que implica um milagre cujo acontecimento guarda independência em relação a todo tipo de contributo humano no sentido de promover o seu crescimento, incrementando-o.

O ser humano não pode acelerar o curso dos acontecimentos estabelecido por Deus, quer seja - conforme a opinião dos fariseus - por meio de rigoroso cumprimento dos mandamentos e por meio de exercícios de penitência, quer seja - como presumem os zelotes - por meio da expulsão dos romanos pela força das armas. (BULTMANN, 2008b, p. 44-45).

Sobrepondo-se à concepção que atribui ao reino de Deus a necessidade de intervenção humana no sentido de promover o seu crescimento, na medida em que consistiria em uma grandeza que se desenvolveria na história, razão pela qual encerraria a condição de um processo que implicaria uma evolução gradual em sua instauração, o que se impõe ao reinado de Deus é a sua absoluta independência em relação a qualquer tipo de contributo humano no sentido de empreender o seu progresso, conforme pressuposto na imagem da parábola da semente em virtude da sua capacidade de crescer por si mesma, visto que tal capacidade se mantém sob tal acepção, constituindo-se a parábola do grão de mostarda e a do fermento uma construção que, em suma, estabelece o contraste entre a insignificância que caracteriza o início

10 "E, saindo os fariseus, puseram-se a discutir com ele; e, tentando-o, pediram-lhe um sinal do céu" (Mc 8,11 , p. 1160). Convergindo para as fronteiras que encerram o sentido de milagre extraordinário, o "sinal do céu", assim definido tanto por Lucas $(11,16)$ como por Mateus $(16,1)$, guarda correspondência com uma manifestação do tipo do maná de Moisés ou da chuva de Elias, cuja grandeza provaria, segundo os fariseus e os escribas, o caráter messiânico da missão de Jesus: "Jesus responde que outro sinal não lhes será dado senão o de Jonas, o profeta (Mt 12,39; v 40 explica: 'do mesmo modo como Jonas esteve três dias e três noites no ventre do peixe, assim o Filho do Homem estará três dias e três noites no seio da terra', i. é, no sepulcro, ou no reino dos mortos, que se colocava debaixo da terra). Mt refere-se certamente à morte e ressurreição de Jesus, o 'sinal de Jonas', conforme a exegese tradicional" (DICIONÁRIO, 2014, p. 1442). 
e a grandiosidade que caracteriza o fim, tornando-se irredutível à interpretação que se detém na série de ações e reações que prático-objetivamente ou teórico-conceitualmente permanecem imbricadas no processo que porventura atrela o começo ao fim (e o fim ao começo).

Constituindo-se em Sua pessoa o sinal do tempo, Jesus em sua pregação anuncia que o reino de Deus está chegando em um processo que encerra o tempo da decisão e implica o chamado à decisão, ${ }^{11}$ convergindo para as fronteiras que envolvem um "estar de prontidão" ou um "preparar-se" como a condição que o ser humano pode assumir diante da irrupção do reino de Deus. Dessa forma, representando em Sua pessoa a exigência da decisão ${ }^{12}$, Jesus, segundo a perspectiva histórica dos sinóticos, se dispõe a assinalar outro, a saber, o "Filho do homem", que não é senão Ele mesmo após a morte, ressurreição e ascensão, o que implica uma condição que não reivindica o reconhecimento em forma de fé em Sua pessoa, nem se autoproclama o "Messias", mas se limita a chamar à decisão, haja vista consistir em um chamado que se impõe como a palavra de Deus antes do fim.

Todos, porém, devem decidir em que querem prender seu coração: em Deus ou nos bens deste mundo. "Não acumuleis tesouros na terra! (...) Pois onde está teu tesouro, aí está também o teu coração!” (Mt 6.19-21 par.) "Ninguém pode servir a dois senhores!” (Mt 6.24 par.). Como é perigosa a riqueza! É mais fácil um camelo passar pelo fundo de uma agulha do que um rico entrar no reino de Deus!" (Mt 10.25) A maioria das pessoas está presa a bens e preocupações; quando é preciso tomar uma decisão, fracassam - como mostra a parábola da ceia (Lc 14.15-24 par.). É preciso decidir com clareza o que se quer, quanto esforço se é capaz de fazer, assim como para a construção de uma torre ou para uma expedição guerreira devem ser previamente calculados os recursos (Lc 14.28-32). Para o reino de Deus, porém, o que conta é estar disposto a qualquer sacrifício - assim como o lavrador que encontra um tesouro e empenha tudo que possui para tomar posse dele, ou como o negociante que vende tudo para adquirir uma pérola preciosa (Mt 13.44-46). (BULTMANN, 2008b, p. 47-48).

11 Detendo-se na proclamação do reino de Deus nas parábolas de Jesus, Helmut Koester observa que “apesar de estar preservadas apenas em suas reformulações gregas, elas parecem ser uma característica distintiva da proclamação do reino de Deus feita por Jesus. As parábolas eram originalmente livres de toda interpretação alegórica (interpretações como, por exemplo, Mc 4,13-20 e Mt 13,36-43 são certamente adições secundárias) e não serviam ao propósito de ilustrar a proclamação de Jesus. Antes, elas são convites que desafiam o ouvinte a entrar numa nova possibilidade do reino de Deus. Elas abrem para o ouvinte o horizonte de uma nova compreensão da existência sob uma perspectiva escatológica, não servindo como explicações, mas conclamando à decisão de entrar" (KOESTER, 2005, p. 92).

12 "As pessoas que se encontravam com Jesus eram colocadas diante da decisão, se aceitavam essa irrupção do futuro de Deus no seu presente e dessa maneira se deixavam arrebatar pela ação salvífica de Deus, ou se pretendiam excluir-se dessa oferta de salvação ao rejeitarem Jesus.” (KÜMMEL, 2003, p. 114). 
Nesta perspectiva, constituindo-se a última hora ou o tempo do fim, Jesus chama à decisão que, convergindo para a radicalidade, impõe a escolha entre Deus ou o mundo, que demanda a renúncia de tudo que o representa e o implica em um processo que envolve a própria negação de $\mathrm{si}^{13}$ como condição para o ser humano tornar-se discípulo, haja vista a incompatibilidade fundamental entre Deus e o seu reinado e o mundo e os seus bens em uma construção que assinala que o vínculo com este último produz efeitos capazes de reduzir o poder de decisão e obliterar o exercício da liberdade que encerra como tal, na medida em que o reinado de Deus requer a disposição sacrificial sem medida do seu seguidor. ${ }^{14}$

Caracterizando-se como um processo de "desmundanização", a renúncia ao mundo se sobrepõe ao caráter de uma ascese ${ }^{15}$, consistindo em uma disposição para o reinado de Deus em um processo que implica, em suma, a necessidade de corresponder à exigência de Deus, na medida em que envolve o cumprimento da vontade de Deus, perfazendo um movimento que converge para uma antecipação da situação escatológica, que implica a ruptura absoluta em face de qualquer bem de caráter material ou imaterial que porventura possa representar a limitação da liberdade do ser humano em sua relação com o reino de Deus, constituindo-se um obstáculo envolvendo a sua participação e exercício.

\section{Da obediência escatológica enquanto realização da vontade de Deus e o amor como base da ética escatológico-existencial}

Contrapondo-se ao legalismo judaico, a pregação de Jesus enquanto exposição da vontade de Deus se sobrepõe ao caráter de uma piedade cuja interpretação da vontade de Deus se circunscreve às fronteiras que envolvem a lei escrita e a tradição em um processo que torna o cumprimento de suas prescrições o meio de conquista da benevolência de Deus.

Não havendo distinção entre religião e ética, a lei prescreve os mandamentos da veneração de Deus e as exigências da ética conjuntamente com as determinações do direito em uma construção que, dessa forma, também reúne sob a égide de lei divina direito civil e direito penal, encerrando sob

13 Cf. Marcos. 8.34; Mateus 16.24; Lucas 14.26-27.

14 Cf. Lucas 14.15-24; 14.28-32; Mateus 13.44-46.

15 Longe de consistir em uma ascese de santidade, conforme a conduta característica dos essênios, tal condição implica a exigência de desprendimento e dissociação de toda e qualquer dependência e compromisso de vínculos que se sobreponham ao caráter absoluto do relacionamento envolvendo o ser humano e Deus na experiência existencial que implica o reinado divino (Mateus 10.37; 19.12.21; Marcos 10.29s.; Lucas 14.26). 
a condição de lei as prescrições envolvendo religião e ética, convergindo para as fronteiras que assinalam a vigência indevida de preceitos legais que, em virtude de terem perdido a capacidade de corresponder às necessidades histórico-culturais da vida concreta do povo, demandam atualização.

Dessa forma, sobrepondo-se às verdadeiras exigências do bem, os mandamentos cúlticos e rituais permanecem nas fronteiras que envolvem a exigência de Deus ou a exigência ética, convergindo para um processo que tende a corromper a motivação para a ação ética, na medida em que o seu fundamento torna-se a ideia de retribuição em uma construção que caracteriza a obediência devida a Deus como um cumprimento formal da letra através de um movimento que prescinde da interrogação pelo sentido do mandamento e impossibilita um exercício radical e autêntico.

E embora alguns escribas protestem contra o fato de se considerar a ideia da retribuição como motivação da obediência, ao exigirem uma obediência de coração, que cumpre o mandamento não somente por temor, mas também por amor a Deus, a obediência não pode ser uma obediência radical e autêntica enquanto a pessoa obedece somente porque algo é ordenado e que, portanto, faria outra coisa se fosse ordenada outra coisa ou não faria essa mesma coisa se não se encontrasse no mandamento. Obediência radical é possível somente onde o ser humano compreende a exigência e concorda com ela a partir de si mesmo. E somente dessa obediência faz sentido dizer que cumpre a exigência de Deus no cumprimento da exigência ética, pois Deus exige obediência radical. (BULTMANN, 2008b, p. 49-50).

Se os profetas veterotestamentários, por intermédio de suas mensagens, protestavam contra o povo, contrapondo a sua piedade cultual o direito e a justiça como a exigência de Deus, Jesus, em sua pregação, proclamando a vontade de Deus, sobrepondo-se à questão que implica direito e justiça, exige uma obediência como um exercício radical e autêntico em lugar da obediência formal sintetizada pelo cumprimento das prescrições rituais.

Opondo-se à perspectiva que, baseada no direito codificado, institui uma relação com Deus que converge para as fronteiras do direito, Jesus exige uma obediência que implica um exercício radical e autêntico em um processo que encerra o ser humano em sua totalidade, haja vista que o controle e o domínio sobre a ação e a conduta, pressupostos da lei, não guarda capacidade de fundamentar a relação com Deus, na medida em que as fronteiras nas quais tal comportamento guarda raízes, a saber, a vontade humana, escapa ao seu poder e determinação.

Circunscrita à possibilidade de determinar o ato e o comportamento através de seus mandamentos e prescrições, a lei, contudo não guarda capacidade de fundamentar a relação com Deus, na medida em que esta implica 
uma obediência como um exercício radical e autêntico que, como tal, demanda o envolvimento do ser humano em sua totalidade em um processo que converge para as fronteiras que encerram a vontade humana e a sua total disposição para cumprir a vontade de Deus.

Deus exige obediência radical, reivindica o ser humano todo. Por isso, para Jesus, que espera que o ser humano pratique o bem, é óbvio que a exigência ética é a exigência de Deus; nesse sentido, também para ele religião e ética formam uma unidade. Mas foram removidas da exigência de Deus todas as determinações cúlticas e rituais, de modo que, ao lado da ética, fica exposta a relação puramente religiosa com Deus, na qual o ser humano se encontra somente como que pede e recebe, como quem espera e confia. (BULTMANN, 2008b, p. 51).

Conciliando radicalização e permissão, como pressupõem as leis e mandamentos que tratam de ações e condutas relacionadas, respectivamente, às prescrições que implicam o homicídio, o adultério e o perjúrio, como também às prescrições que envolvem o divórcio, o ius talionis e o amor ao "próximo", a pregação de Jesus em sua exposição da vontade de Deus, longe de se deter nas fronteiras que encerram a ação em sua objetividade, tende a se inclinar sobre as suas raízes, convergindo para a subjetividade em um processo que, em relação ao agir e ao comportamento, sobrepõe o "como" ao "o quê".

O ser humano, exigido em sua totalidade, não tem liberdade diante de Deus; ele tem que responsabilizar-se - como mostra a parábola dos talentos (Mt 25.14-30 par.) - por sua vida como um todo. Perante Deus, ele não tem exigências a fažer, antes é comparável ao escravo que somente deve e pode cumprir seu dever (Lc 17.7-10). (BULTMANN, 2008b, p. 52).

Exigindo uma obediência incondicional, Jesus, em sua pregação, usa a imagística de uma criança em sua incapacidade cognitiva para assinalar o paradigma que o ser humano deve corresponder na sua relação com Deus, convergindo para um estado que ignora direitos e méritos e, consequentemente, escapa à condição que tende ao orgulho e à soberba, na medida em que a promessa em face da obediência guarda correspondência com uma prática incondicional cujo exercício, radical e autêntico, se sobrepõe às fronteiras que implicam a expectativa de recompensa. ${ }^{16}$

\footnotetext{
16 "Então, lhe trouxeram algumas crianças para que as tocasse, mas os discípulos os repreendiam. Jesus, porém, vendo isto, indignou-se e disse-lhes: Deixai vir a mim os pequeninos, não os embaraceis, porque dos tais é o reino de Deus. Em verdade vos digo: Quem não receber o reino de Deus como uma criança de maneira nenhuma entrará nele. Então, tomando-as nos braços e impondo-lhes as mãos, as abençoava.” (BÍBLIA DE ESTUDO DE GENEBRA, Marcos 10.13-16, 1999, p. 1164-1165).
} 
Se a noção envolvendo retribuição e recompensa emerge no discurso de Jesus em uma construção que implica a necessidade de suscitar uma carga de motivos que seja capaz de produzir a obediência, convergindo para um movimento que, longe de engendrar uma conduta cujo exercício permaneça atrelado mecanicamente ao efeito proposto, encerra a possibilidade de instauração de uma experiência existencial em relação ao próprio ser através de um processo paradoxal que assinala que uma disposição absoluta no sentido de cumprir a exigência de Deus pelo agir ético em sua radicalidade e autenticidade constitui-se, em suma, em uma perda de si que torna-se em uma realidade oposta, a saber, a conquista de si mesmo.

Então, convocando a multidão e juntamente os seus discípulos, disse-lhes: Se alguém quer vir após mim, a si mesmo se negue, tome a sua cruz e siga-me. Quem quiser, pois, salvar a sua vida perdê-la-á; e quem perder a vida por causa de mim e do evangelho salvá-la-á. Que aproveita ao homem ganhar o mundo inteiro e perder a sua alma? (BÍBLIA DE ESTUDO DE GENEBRA, Mc 8,34-36, 1999, p. 1161).

A noção que envolve retribuição ou recompensa em relação à obediência incondicional que implica a exigência de Deus como um exercício radical e autêntico converge, segundo a pregação de Jesus, para as fronteiras que encerram a disposição absoluta do ser humano no sentido de corresponder à vontade de Deus em um movimento que envolve a entrega total de si, que pressupõe a negação de si através da renúncia da própria vontade como tal, assim como da vida mesma enquanto produção histórico-cultural. ${ }^{17}$

Seu chamado ao discipulado não implica a promessa de paraíso na terra como resultado do cumprimento do mandamento do amor. Quem quer seguir a Jesus deve estar preparado para sofrer, e os discípulos terão de arriscar suas vidas (Mc 8,34-35). Discipulado significa renúncia à própria segurança (Lc 9,62; 14,26), o que não exclui comportamento inteligente e prudente. (KOESTER, 2005, p. 96).

Evitando se contrapor à legislação veterotestamentária e a sua autoridade, Jesus institui uma distinção crítica envolvendo as prescrições e as exigências da Lei que, no Antigo Testamento, expressam a vontade de Deus, convergindo para uma construção que assinala que não basta cumprir os mandamentos formalmente, pressuposto de uma relação mecânica que se esgota nas fronteiras da aparência em virtude de sua incapacidade de se deter no dito que se expõe como a vontade petrificada de Deus em um processo que atribui à letra o poder de condensá-la e comunicar ao ser humano as

17 Cf. Marcos 8.35; Mateus 10.39; 16.25; Lucas 9.24; 17.33; João 12.25. 
determinações de Deus em sua totalidade ético-religiosa, político-jurídica, econômico-social, histórico-cultural.

Se os mandamentos se caracterizam como necessários para regular o relacionamento dos seres humanos entre si, tanto quanto diante de Deus, o seu cumprimento não pressupõe o esgotamento da vontade de Deus, na medida em que tal concepção tende a torná-la redutível às prescrições e mandamentos da Lei, convergindo para suprimir a vitalidade e o dinamismo que perfazem a identidade de Deus como tal diante de seu povo.

Dessa forma, se Jesus em sua pregação se opõe aos escribas e fariseus em um processo que implica divergência em relação às fronteiras teórico-conceituais (intepretação e compreensão) e prático-objetivas (aplicação das prescrições e mandamentos da Lei), a sua proclamação da vontade de Deus não envolve de forma alguma a negação da validade das Escrituras Sagradas judaicas, ${ }^{18}$ na medida em que, longe de se contrapor à disposição de dar esmola, orar e jejuar, que perfazem costumes do judaísmo em sua representação de piedade, o seu protesto e advertência veemente se dirige ao modo mediante o qual tal exercício é realizado, haja vista que, em suma, tornam-se atividades de autopromoção dos praticantes que, prestando aparentemente um serviço a Deus, incorrem na honra de si mesmos e na sua própria auto-exaltação em detrimento da glória devida somente a Deus ${ }^{19}$.

Se o culto do templo havia perdido o seu sentido nas fronteiras histórico-culturais da epocalidade de Jesus, tal condição, que assinalava a transformação do judaísmo em uma religião da observância (ético-religiosa) em detrimento do caráter teológico-existencial de religião cúltica, jamais se constituiu um objeto de polêmica capaz de provocar a reação contrária de

18 "Não penseis que vim revogar a Lei ou os Profetas; não vim para revogar, vim para cumprir. Porque em verdade vos digo: até que o céu e a terra passem, nem um i ou um til jamais passará da Lei, até que tudo se cumpra” (Mt 5,17-18, p. 1106-1107). Cabe esclarecer que $i$ corresponde ao grego iota e ao hebraico yod (ou yôdh), representando em ambos a menor letra, enquanto o til, equivalendo ao grego keraia (literalmente significando “chifrezinho"), consistia no sinal que distinguia determinadas consoantes hebraicas, o daleth do rêsh, o bêth do kaph. Dessa forma, atribuindo ao conteúdo em questão a condição de expressão da consciência de plenipotência de Jesus, Joachim Jeremias obtém a seguinte conclusão: "Jesus, pois, respondendo à insinuação (mè nomísate) de que ele é antinomista, está dizendo que sua tarefa não é a dissolução da Tora, mas sua complementação. A tradução de 'osope ('acrescentar') [aramaico que corresponde ao significado de 'aumentar, acrescentar, alargar'] por plerôsai no grego [que encerra o sentido de ‘completar'] expressa adequadamente que o propósito da ‘complementação’ é atingir a medida completa. Temos aí a ideia da medida escatológica, que Jesus usa também em outros lugares; plesôrai é, portanto, termo técnico escatológico. Em outras palavras, com o lógion de Mt 5,17 Jesus está a reclamar para si ser o mensageiro escatológico de Deus, o profeta prometido igual a Moisés (Dt 18,15.18), que é o portador da revelação definitiva e que, por isso, exige obediência absoluta" (JEREMIAS, 1977, p. 133).

19 Cf. Mateus 6.1-4, 5-8, 16-18. 
Jesus às reuniões e às celebrações cúlticas realizadas no templo no sentido de destituí-las do valor simbólico ou desautorizá-las como lócus do serviço prestado a Deus através do exercício da piedade em forma de louvor, adoração e meditação das Sagradas Escrituras. ${ }^{20}$

Sobrepondo-se às prescrições cúlticas e rituais que compõem a legislação veterotestamentária, Jesus diverge da acepção imposta pelo judaísmo e pela tradição ao mandamento do sábado, ${ }^{21}$ contrapondo-se ao ritualismo legal em uma experiência que guarda capacidade de correlacionar obediência piedosa e vontade ímpia, a saber, obediência em conformidade com as prescrições e mandamentos da Lei através de um comportamento exterior adequado à legislação veterotestamentária e vontade em discordância com os referidos preceitos, convergindo para as fronteiras que encerram a incompatibilidade entre as esferas prático-objetiva e subjetivo-volitiva. ${ }^{22}$

Sobrepondo-se ao cumprimento dos mandamentos como uma obrigação que guarda raízes nas fronteiras do sistema ético-religioso do judaísmo, Jesus não contesta o valor das prescrições da Lei em si senão o modo pelo qual a experiência de obediência é instaurada, na medida em que se o seu sentido implica a mediação envolvendo a relação entre Deus e o seu povo, individual e coletivamente, a condição que assume no processo converge para impossibilitar o ser humano de corresponder à vontade de Deus que a legislação veterotestamentária detém e que, em suma, traz como exigência o amor. ${ }^{23}$

A ética escatológica remove o pretexto da segurança da lei; a lei não pode mais ser usada como um véu atrás do qual os homens podem esconder-se quando se confrontam com a vontade de Deus. Os impropérios contra os fariseus, embora sejam em sua maioria criações da comunidade, especialmente na forma em que ocorrem em Mateus (Mt 23), também significam que a justiça e a misericórdia são ludibriadas quando a probidade conforme com a lei permite a construção de muros entre os seres humanos (ver especialmente Mt 23,13.16-19.23.25.29).

20 Cabe sublinhar que, sob a acepção de religião da observância, o judaísmo deixou relegado a uma categoria inferior o serviço no templo, atribuindo preeminência aos escribas diante do povo em detrimento dos sacerdotes, convergindo para um processo que impõe à vida cotidiana a interpretação da lei da sinagoga, o que implica a execução de sacrifícios como obediência às determinações da lei em uma construção que confere à condição de um costume natural a frequência e participação nas reuniões e celebrações cúlticas do templo.

21 Na medida em que a tradição institui regras que conferem primazia ao sistema ético-religioso em detrimento da própria vida do ser humano em uma construção que, longe de possibilitar o reconhecimento da sua necessidade em relação a Deus, converge para a exposição de uma ruptura irredutível até às prescrições e mandamentos da Lei, cuja obediência trazia a pressuposição de transposição inconteste.

22 Cf. Isaías 29.13; Marcos 7.6; Mateus 23.25-28.

23 Cf. Marcos 12.28-34. 
O mandamento do amor ao próximo, que já ocupava posição central no judaísmo (Lv 19,18), recebe destaque também na tradição dos ditos de Jesus, mas é rejeitado quando se torna a única regra de conduta social (Mt 5,46-47), e substituído pelo amor aos inimigos (Mt 5,44). (KOESTER, 2005, p. 96).

Dessa forma, a exigência do amor guarda correspondência com a vontade de Deus, na medida em que a omissão consiste em uma conduta que converge para as fronteiras que encerram o próprio mal em um movimento que torna-se incapaz de isentar de responsabilidade ou manter incólume o que se abstém de agir como se a recusa de fazê-lo ou o esvaziamento do ato no "não" não consistisse na atitude mesma que implica "nada fazer" em um processo que traz subjacente a possibilidade oposta, que assim é objetada, posto que passível de recusa, haja vista a necessidade de que a obediência a Deus seja um exercício que, em sua radicalidade e autenticidade, longe de se circunscrever à dimensão da liberdade subjetiva, ${ }^{24}$ não deixe de contemplar a alteridade em uma construção que se exteriorize na concreticidade histórico-cultural da relação intersubjetiva. ${ }^{25}$

A exigência do amor não necessita de disposições formuladas; o exemplo do samaritano misericordioso mostra que a pessoa pode e deve saber o que tem de fazer ao ver o próximo precisando de sua ajuda. No "como a ti mesmo" do mandamento do amor está predeterminado tanto o caráter ilimitado da prática do amor, quanto a sua direção. (BULTMANN, 2008b, p. 57).

Sobrepondo-se às exigências do direito em sua totalidade, a determinação do amor transpõe as fronteiras jurídico-políticas, econômico-sociais, histórico-culturais, étnico-raciais, entre outras, convergindo para um processo que implica a intersubjetividade em sua relação com a alteridade, inclusive diante dos opositores propriamente ditos, haja vista que pressupõe a possibilidade de seu exercício, tanto quanto a capacidade cognitiva e moral de agir em função da alteridade através de um processo irredutível a um conjunto

24 Nesta perspectiva, cabe salientar que "a verdadeira liberdade não consiste em uma arbitrariedade subjetiva, senão que é a liberdade na obediência. A liberdade da arbitrariedade subjetiva é uma ilusão, posto que entrega o homem aos seus próprios impulsos, obrigando-o a fazer em cada momento o que os seus desejos e suas paixões lhe ditam. Na realidade, esta liberdade vazia é sujeição ao desejo e à paixão de cada instante. A verdadeira liberdade é a que não se subordina às incitações do momento, a que resiste à chamada e à pressão das motivações momentâneas. Isto somente é possível quando a conduta está determinada por um motivo que transcende o momento presente, isto é, por uma lei. A liberdade é obediência a uma lei cuja validez é reconhecida e aceita, uma lei que o homem reconhece como a lei de seu próprio ser. Só uma lei que tenha sua origem e sua razão de ser no mais além, pode cumprir estas condições. Podemos lhe dar o nome de lei do espírito ou, em linguagem cristã, lei de Deus." (BULTMANN, 2008a, p. 33)

25 Cf. Lc. $10.29-37$. 
de normas e prescrições individuais que escapa a condição de um projeto intramundano e perfaz, em suma, a ética escatológica, que exige do ser humano a abdicação de seu próprio direito em face da alteridade, tornando-o totalmente responsável perante Deus.

\section{O dever-ser e o poder-fazer envolvendo o bem incondicional na consciência da situação-limite da existência}

Transcendendo a ordenança da comunhão humana, a ética escatológica requer do ser humano a abdicação do seu próprio direito em face da alteridade em um processo que o torna enquanto tal totalmente responsável perante Deus, convergindo para as fronteiras que encerram a unidade envolvendo a pregação escatológica, que implica o anúncio da irrupção do reino de Deus, e a pregação ética de Jesus, que implica a explicação da lei de Deus.

Escapando à condição de um dever que converge para as fronteiras da formação do caráter, como também ao princípio de determinação da comunhão humana, a exigência do amor se impõe à pregação escatológica de Jesus e a sua pregação ética, perfazendo uma unidade que se sobrepõe à construção teórico-conceitual que atribui ao reino de Deus a condição de uma grandeza espiritual ou histórica, sob a acepção que envolve o reinado de Deus na alma ou na história em um processo cuja concretização guarda correspondência com o governo ou o domínio do bem através de um movimento que encerra como fundamento a experiência que, individual ou coletivamente, implica o caráter e a atitude ética ou a comunhão e a ordem ética.

A proclamação ética de Jesus foi interpretada de várias maneiras. Ela foi entendida como ética escatológica, isto é, uma moralidade especial válida somente para o breve intervalo que precede a vinda de Deus (ou do Messias); como formulação de uma moralidade superior só alcançável em teoria; como padrão moral cujo objetivo é ressaltar a condição pecadora do homem; finalmente, como recomendação "evangélica" para uma moralidade mais elevada de um grupo seleto. Além disso, essa proclamação ética é quase sempre vista como dirigida a indivíduos, a seus problemas morais ou à sua condição pecadora. Com essa interpretação individualista relaciona-se estreitamente o pressuposto de que a validade dos preceitos de Jesus é limitada. No entanto, na forma como os ensinamentos éticos de Jesus estão preservados nos evangelhos, especialmente no Sermão da Montanha (Mt 5,7), é evidente que são dirigidos a uma comunidade e que têm o propósito de regular a conduta moral e religiosa dessa comunidade. Com efeito, todos os aspectos lembrados do ensinamento de Jesus só estão preservados porque tinham utilidade para a vida da comunidade que se considerava o povo escatológico de Israel. Embora seja improvável que Jesus se visse como organizador de uma nova comunidade - e certamente não como fundador da igreja — também é improvável que tivesse algum interesse em formar indivíduos morais. Se ele entendia sua missão em 
termos dos profetas de Israel, seu ensinamento moral deve ter sido dirigido ao povo de Israel como um todo. No horizonte da vinda do reino de Deus, seu ensinamento ético é então o esboço para os limites morais do povo escatológico de Deus, isto é, para a ética escatológica, mas não no sentido de ética para um período temporário. (KOESTER, 2005, p. 94-95).

Longe de sobrepor a pregação ética à mensagem escatológica, que atribui a Jesus a condição de um mestre cujo trabalho implica o ensino de princípios de justiça para uma comunidade que, posteriormente, o transforma em profeta da irrupção do reino de Deus, a tradição assinala que a instituição da comunidade guarda correspondência com a expectativa e apreensão em relação ao reinado de Deus e a demora da sua implantação como tal em uma construção que encerra uma pregação escatológica cujo conteúdo mantém raízes histórico-culturais em um processo que também não pode relegar ao caráter de uma formação secundária o discurso ético, na medida em que não haveria lógica em imputar o status de rabino a um líder que antes era considerado Messias.

Consistindo no cumprimento da vontade de Deus, a mensagem escatológica e a pregação ética perfazem uma unidade que implica a condição que converge para as fronteiras que encerram o reinado de Deus e a participação na sua salvação em uma construção cujos imperativos, sobrepondo-se ao caráter de mandamentos de exceção, constituem um conteúdo que carrega a radicalidade de uma exigência absoluta ${ }^{26}$.

Guardando uma validade que se sobrepõe ao caráter geográfico-temporal e histórico-cultural, os imperativos do "sermão do monte" não emergem como exigências que têm como origem a iminência do fim do mundo, assim como não está fundado nesta realidade da pregação de Jesus o seu discurso e posicionamento contra a moral legalista, na medida em que é a exigência de Deus e o conhecimento da sua validade absoluta que converge para as fronteiras que encerram o juízo que em sua radicalidade a mensagem escatológica expressa em um processo que torna o cumprimento da vontade de Deus a condição para o reinado de Deus em um movimento que implica disposição e autêntica vontade no sentido de uma decisão existencial em relação a Deus capaz de produzir a ruptura necessária de todos os liames envolvendo o mundo.

26 De acordo com Ridderbos, Bultmann "chama o cumprimento da vontade de Deus de condição de participação na salvação do reino. Entretanto, ele [Bultmann] quer demonstrar a unidade da pregação ética e escatológica. O reino dos céus é uma realidade presente na medida em que conclama o homem ao arrependimento e o confronta com a grande decisão (Entscheidung). Os mandamentos não servem a nenhum outro propósito. No fundo, eles são supraéticos. Como a pregação do reino, os mandamentos mostram ao homem a sua 'presente' realidade como a hora de decisão diante de Deus" (RIDDERBOS, 2010, p. 184-185, grifo do autor). 
Quem quer o reinado de Deus também quer cumprir o mandamento do amor e, no fundo, ao cumpri-lo como condição, sua vontade não visa a outra coisa, para cuja obtenção somente ele presta obediência. Existe, portanto, um nexo interno: ambas, a pregação escatológica tanto quanto a exigência ética mostra ao ser humano sua condição de estar colocado diante de Deus, diante da iminência de Deus; elas o remetem ao seu agora como sendo a hora da decisão a favor de Deus. (BULTMANN, 2008b, p. 59).

Lamento e conclamação à penitência, eis o que se impõe à pregação de Jesus em um contexto histórico-cultural que encerra como características das lideranças e do povo uma piedade ritualístico-legalista ${ }^{27}$ ou formalístico ${ }^{28}$ cerimonialista $^{29}$ através de uma construção religiosa que implica leviandade e amor ao mundo, assim como o amor próprio.

Sintetizando a pregação de Jesus, o convite ou convocação ao arrependimento encerra como destino uma geração cuja conduta ético-religiosa, embora aparentemente demonstre a pretensão de cumprir a exigência de Deus, converge para as fronteiras de um exercício destituído da condição sine qua non para a instauração da experiência existencial que implica uma obediência baseada em uma disposição que emerge da interioridade e envolve o ser humano em sua totalidade em um movimento capaz de superar as oposições da exterioridade e as autorresistências imbricadas na sua própria estrutura ético-intelectual, mental-orgânica, psicológico-fisiológica, afetivo-cognitiva, volitivo-consciencial.

O que, porém, Jesus quer dizer ao exigir: convertam-se? De novo é típico que os termos metánoia e metanoeîn não expressam exaustivamente o que Jesus entende por conversão. As parábolas falam linguagem mais clara, distinguindo-se especialmente a do filho perdido, pela clareza e simplicidade. A mudança em sua vida se descreve como eis heautòn dè elthón (Lc 15,17), em cujo fundo deve estar o aramaico hadar be, que não significa como a fórmula grega "ele voltou a um estado racional de ânimo", mas sim "ele se converteu". O que é de maior importância aí é o fato de ele reconhecer a sua culpa (v. 18). O publicano faz o mesmo; "Ele não ousava levantar os olhos para o céu”, e muito menos (assim se deve completar) as mãos (Lc 18,13). Em vez do gesto costumeiro da oração, levantar mãos e olhos, ele bate desesperadamente no peito, acompanhando o gesto com as palavras do começo do S1 51, que ele amplia com o dativo (entendido adversativamente!) tô hamartolô: "Ó Senhor, tende piedade de mim, ainda que eu seja tão pecador!” (JEREMIAS, 1977, p. 235-236).

Guardando correspondência com a situação concreta do contexto histórico-cultural, político-jurídico e econômico-social, entre outros fatores

27 Cf. João 7.23 .

28 Cf. Isaías 1.13; 29.13; 58.2; Mateus 15.8; 23.23; Gálatas 4.10-11; Colossenses 2.20; IITimóteo 3.5.

29 Cf. Marcos 7.4; Atos 15.20; Gl. 4.9; 5.1; Colossenses 2.20; Hebreus 9.10. 
que se inter-relacionam na sua disposição, o arrependimento implica um movimento de retorno ${ }^{30}$ à condição psicológico-volitiva pré-autocêntrica ou pré-autocrata em um processo que converge para a restauração da vitalidade ético-intelectual, mental-orgânica, psicológico-fisiológica, afetivo-cognitiva, volitivo-consciencial, por intermédio de uma construção cuja autenticidade existencial guarda correspondência com uma busca que tem como fim Deus e pressupõe um estado que encerra fome, sede e pobreza ${ }^{31}$ como consciência da impotência fundamental que caracteriza o ser humano em sua relação com o Absoluto e Transcendente, tanto quanto consigo mesmo e com a alteridade. Implicando o dever-ser e o poder-fazer envolvendo o bem incondicional em uma construção teórico-conceitual e subjetivo-existencial que impõe a consciência da situação-limite da existência e a necessidade de uma decisão existencial, o conhecimento da inviolável vontade de Deus converge para a unidade da pregação ético-escatológica de Jesus em um processo que expõe o seu verdadeiro sentido que, trazendo subjacente a ideia de Deus, encerra a expectativa do juízo de Deus em relação ao futuro através de um movimento que em virtude da incomensurabilidade de Deus como Absoluto e Transcendente tende a atribuir ao mundo enquanto totalidade finita o caráter de uma realidade que necessariamente emerge como imperdurável, configurando-se como um todo inevitavelmente destinado ao fim, cujo evento não guarda possibilidade de que seja senão iminente e catastrófico, haja vista o seu estado de total e irreversível antagonismo em relação a si mesmo.

O fim do mundo é, pois, o juízo de Deus; isto é, a pregação escatológica não se limita em nos tomar conscientes da futilidade da situação humana e a chamar aos homens, como faziam os gregos, à moderação, à humildade e à resignação: os chama, antes de tudo e, sobretudo, à responsabilidade para com Deus e ao arrependimento. Exorta-os a cumprir a vontade de Deus. E aqui se toma evidente a diferença característica entre a pregação escatológica de Jesus e a dos apocalipses judaicos: todas as descrições da felicidade futura, nas que sobressai a literatura apocalípitica, estão ausentes da pregação de Jesus. (BULTMANN, 2008a, p. 22).

Longe de consistir em uma pregação cujas raízes remetem às fronteiras da indisposição diante do mundo e da incompatibilidade em face de suas práticas, valores e objetivos, o discurso ético-escatológico de Jesus traz como fundamento o conhecimento da vontade de Deus em uma construção que

\footnotetext{
30 "Uma das concepções fundamentais do judaísmo da época de Jesus era a de que o homem deve dar 'meia-volta', caso quiser subsistir diante de Deus. De modo que também Jesus mencionou explicitamente o arrependimento como condição para a entrada no reino de Deus (Mt 11.21s par.; Lc 16.29s)". (KÜMMEL, 2003, p. 65)

31 Cf. Lucas 6.20; Mateus 5.3-6.
} 
envolve a consciência do caráter fútil e corruptível, seja do mundo, seja dos seres humanos, convergindo para as fronteiras que se sobrepõem à iminência temporal do fim e encerram um viés teológico e antropológico que assinalam, respectivamente, um Deus em atuação, sob a acepção de "Agente divino-humano escatológico cósmico-histórico-existencial”, e uma existência em sua especificidade cósmico-histórica, no sentido de existência escatológica.

A condição inalienável de uma disposição em relação ao Criador e a sua vontade, eis o que se impõe ao ser humano em um movimento que encerra a ideia de sujeição, submissão, domínio, rendição, comprometimento, o que implica uma inevitável correspondência que converge para as fronteiras que assinalam tendência, inclinação, propensão, desígnio, propósito, determinação, e que se sobrepõe à unilateralidade que prescinde da oposição em função de uma harmonia que tende a abolir o atrito e a ruptura do exercício da liberdade subjetiva em sua totalidade finita e afirma a dialética vital imbricada na relação entre o ser humano e Deus.

Se o Antigo Testamento e o Judaísmo em sua construção teológico-dogmática e ético-religiosa baseada na fé em Deus como Criador, a sua religiosidade, contudo, se mantém sob a égide que afirma o afastamento de Deus para o além em um processo que implica a sua institucionalização como rei celestial, convergindo para um movimento que envolve a redução progressiva da sua ação e influência na vida histórico-cultural e geográfico-temporal do seu povo, carregando a pregação ético-escatológica de Jesus uma mensagem que traz Deus como Deus da proximidade através de uma construção que Lhe atribui a condição de um poder em exercício que impõe limitações e guarda capacidade de desafiar o ser humano no sentido de produzir a consciência de si como correspondência ao reconhecimento que o existente singular deve a Deus como Senhor e Pai.

O Deus da exigência e do juízo, porém, é também o Deus do perdão; e quem retoma a ele pode ter certeza de sua bondade perdoadora. Os escribas trancam o reino de Deus diante das pessoas por meio de seu legalismo (Mt 23.13 par.): a conclamação de Jesus à penitência justamente o franqueia, não havendo necessidade de longas orações de penitência, como são características do judaísmo. O publicano que não ousa erguer os olhos ao céu, que bate no peito, dizendo: "Deus tenha piedade de mim pecador!", é justificado (Lc 18.9-14). O filho "perdido" diz apenas: "Pai, pequei contra o céu e contra ti; já não sou digno de ser chamado teu filho" - e em seguida a bondade paterna o abraça (Lc 15.11-32). Os orgulhosos e os da justiça própria são abominação para Deus (Lc 16.15; 18.9-14), mas Deus se alegra com o pecador que se converte arrependido (Lc 15.110). O perdão, porém, só foi recebido realmente, se ele toma o coração bondoso, como ensina a parábola do "servo implacável" (Mt 18.23-35; cf. Lc 7.47), e somente quem está disposto a perdoar pode pedir sinceramente o perdão de Deus (Mt 6.12,14s.). 
O perdão de Deus renova a pessoa; e quem quer renovar-se, recebe-o. (BULTMANN, 2008b, p. 63, grifos do autor).

Se a vontade determina a singularidade do ser humano, a condição de Deus como Deus da proximidade implica simultaneamente a caracterização de sua vontade que, irredutível à letra da lei e à explicação dos escribas em sua interpretação ético-religiosa e histórico-cultural, converge para as fronteiras que encerram a superação da ruptura geográfico-temporal em face dos códigos, regras e normas do arcabouço da legislação e das questões envolvendo a sua aplicação em um contexto que não se coaduna com o seu contexto originário, na medida em que a compreensão se sobrepõe a construção teórico-conceitual e a capacidade do ser humano em elaborar em sua exterioridade e realidade objetiva a obediência, ${ }^{32}$ mas consiste em um movimento que guarda raízes na interioridade do "ser-em-situação" e na sua disposição de dependência de Deus no processo de exteriorização para o qual tende na intersubjetividade.

Sobrepondo-se à concepção que atrela o juízo vindouro de Deus à história do mundo em uma construção que envolve a manifestação de eventos catastróficos, a pregação de Jesus escapa ao sentido imposto à pregação profética como conteúdo extático-verbal que encerra as revelações de Deus no movimento histórico-cultural dos povos, consistindo em uma mensagem que, embora estabeleça a correlação implicando juízo e salvação, atribui a tais fenômenos a condição escatológica stricto sensu, na medida em que os distingue como acontecimentos que põem termo ao mundo e a história em um processo que guarda correspondência com os indivíduos e sobrepuja, dessa forma, o povo como um todo, o coletivo, atribuindo, em suma, responsabilidade aos seres humanos em sua condição individual, convergindo, enfim, para a sua felicidade no porvir.

Se a concepção de Deus segundo a pregação de Jesus tem caráter desistoriz̧ado em um processo que se contrapõe à construção profético-veterotestamentária e encerra uma relação envolvendo Deus e ser humano que escapa às fronteiras históricas do mundo, dialogando com o judaísmo, simultaneamente a perspectiva de Jesus em face de Deus permanece sob a égide de uma noção historizada. Dessa forma, se em conformidade com a interpretação do judaísmo, a desistorização, no tocante a Deus, tem como fundamento a concepção baseada na transcendência de Deus em uma construção teológico-religiosa

\footnotetext{
32 "Assim, se inexiste o recurso a uma ética augusta especial para a construção de um caráter moral do indivíduo, a visão da nova situação humana é, por um lado, única enquanto conclama os seres humanos a uma obediência escatológica especial de acordo com a vontade de Deus como revelada no início da criação." (KOESTER, 2005, p. 96).
} 
que assinala a participação dos seres angelicais como representantes divinos no governo do mundo e impõe a mediação do livro da lei como condição para a relação entre Deus e o ser humano, a desistorização, no que tange ao ser humano, implica um processo de desmundanização que, envolvendo a exclusão do mundo através do rito, converge para a sua integração à comunidade que, em virtude do cumprimento de regras cerimoniais e prescrições cúlticas, encerra a capacidade de proporcionar segurança, estabilidade e firmeza.

Nesta perspectiva, convergindo para a superação do judaísmo, Jesus atribui à desmundanização do ser humano ao processo que implica o chamado de Deus ao indivíduo para uma relação que demanda o seu desenraizamento do mundo enquanto base existencial através de um movimento que encerra a capacidade de inseri-lo na condição ético-escatológica que converge para as fronteiras que envolvem a libertação humana dos vínculos mundanos através de uma construção dialética, na medida em que, embora se sobreponha à história em Sua transcendência, é a história do indivíduo o locus do encontro divino com o ser humano, consistindo a desistorização humana a possibilidade da relação concreta com o próximo e da intersubjetividade que tende a torná-lo autenticamente histórico, visto que

justamente o Deus que se situa além da história do mundo encontra-se com o ser humano em sua respectiva história pessoal, no dia-a-dia, em sua dádiva e exigência; o ser humano desistorizado, isto é, destituído de sua segurança, é remetido ao encontro concreto com o próximo, no qual ele se torna autenticamente histórico (BULTMANN, 2008b, p. 64).

\section{Aspectos conclusivos}

Baseado na condição de discípulo de João Batista, Jesus em sua pregação conserva o conteúdo escatológico da mensagem do seu mestre em uma construção teológica que se sobrepõe à ênfase envolvendo a manifestação de Deus através do Juízo Final e converge para as fronteiras que encerram a proclamação do "governo" ou "realeza" 33 de Deus, o que implica um processo que, longe de se caracterizar como um acontecimento do porvir ou um evento vindouro, emerge por intermédio das palavras de Jesus, mediante as quais é instaurado como tal em um movimento que guarda correspondência com a participação de todos quantos atendem ao convite e se dispõem a celebrar ${ }^{34}$

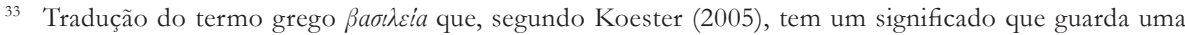
exatidão ou precisão que o termo "reino" não alcança ou corresponde em seu processo de definição.

34 Cabe sublinhar, nesta perspectiva, que a celebração implica uma conduta que estabelece a distinção entre os discípulos de João Batista e os seguidores de Jesus de Nazaré (Mc 2.18-19).
} 
a realização da promessa escatológica. "Portanto, a boa nova de Jesus tem por conteúdo o fato de que, em sua pregação, já agora Deus estabelece o seu reino e que, por essa razão, já é possível participar da ação salvífica de Deus, aderindo com fé a essa proclamação de Jesus" (KÜMMEL, 2003, p. 57).

Convergindo para as fronteiras que encerram o tempo da decisão e o chamado à decisão, o reino de Deus enquanto governo de Deus como acontecimento escatológico demanda em sua irrupção, como base teórico-conceitual da pregação de Jesus, uma atitude que implica um "estar de prontidão" ou um "preparar-se" enquanto obediência escatológica como realização da vontade de Deus e participação na Sua salvação em um processo que converge para a radicalidade e impõe a escolha entre Deus ou o mundo através de um movimento que tende a renúncia absoluta em relação a tudo que possa representá-lo como totalidade finita de valores, práticas e condutas que em virtude de sua própria natureza se opõe a Deus, culminando com a própria negação de si como condição para o ser humano tornar-se discípulo.

Se Jesus não se opõe às prescrições da Lei e aos mandamentos do sistema ético-religioso do judaísmo e a sua condição de mediação entre Deus e o seu povo, individual e coletivamente, é o modo pelo qual a obediência emerge que se impõe como objeto de crítica, na medida em que, baseada na obrigação, o seu exercício não guarda possibilidade de instaurar a correspondência dos seres humanos em relação a vontade de Deus que, em suma, traz como exigência o amor.

Perfazendo uma unidade que converge para as fronteiras que encerram o reinado de Deus, a mensagem escatológica e a pregação ética consiste no cumprimento da vontade de Deus e encerra a possibilidade de participação na Sua salvação em uma construção cujos imperativos se sobrepõem ao caráter de mandamentos de exceção e constituem um conteúdo que carrega a radicalidade de uma exigência absoluta que, tendo como fundamento a renúncia ao mundo, escapa ao caráter de uma ascese de santidade e implica uma ruptura diante de toda e qualquer dependência e compromisso que se sobreponha ao relacionamento entre o ser humano e Deus na experiência existencial do reino de Deus enquanto governo de Deus.

Nesta perspectiva, se a pregação ético-escatológica de Jesus encerra o chamado de Deus ao indivíduo para uma relação que exige a decisão radical envolvendo o desenraizamento do mundo enquanto base existencial, convergindo para a superação do judaísmo, tal experiência existencial emerge como o processo de desmundanização que implica a capacidade de inseri-lo na condição ético-escatológica do reino de Deus enquanto governo de Deus e converge para a sua libertação dos vínculos mundanos em uma construção 
dialética que, se atribui à história do indivíduo a condição de locus do encontro divino, assinala uma relação envolvendo Deus e ser humano que escapa às fronteiras históricas do mundo em um movimento que torna a desistorização humana a possibilidade da relação concreta com o próximo e da intersubjetividade que tende a torná-lo autenticamente histórico.

\section{Referências bibliográficas}

BÍBLIA DE ESTUDO DE GENEBRA. Trad. João Ferreira de Almeida. (Revista e Atualizada). São Paulo; Barueri: Cultura Cristã; Sociedade Bíblica do Brasil, 1999.

BULTMANN, Rudolf. Jesus Cristo e mitologia. Trad. Daniel Costa. 4. ed. São Paulo: Fonte Editorial, 2008a.

BULTMANN, Rudolf. Teologia do Novo Testamento. Trad. Ilson Kayser. Santo André: Academia Cristã, 2008b.

CULLMANN, Oscar. Cristologia do Novo Testamento. Trad. Daniel de Oliveira e Daniel Costa. São Paulo: Custom, 2002.

DICIONÁRIO Enciclopédico da Bíblia. São Paulo: Paulus, 2014.

GOPPELT, Leonhard. Teologia do Novo Testamento. Trad. Martin Dreher e Ilson Kayser. 3. ed. São Paulo: Teológica, 2002.

RIDDERBOS, Herman. A vinda do reino. Trad. Augustus Nicodemus Lopes e Minka Schalkwijk Lopes. São Paulo: Cultura Cristã, 2010.

JEREMIAS, Joachim. Teologia do Novo Testamento. Trad. João Rezende Costa. São Paulo: Paulinas, 1977.

KOESTER, Helmut. Introdução ao Novo Testamento. Vol. 2: História e literatura do cristianismo primitivo. Trad. Euclides Luiz Calloni. São Paulo: Paulus, 2005.

KÜMMEL, Werner Georg. Síntese Teológica do Novo Testamento. Trad. Sílvio Scheider e Werner Fuchs. São Paulo: Teológica, 2003.

VANGEMEREN, Willem A. Novo dicionário internacional de teologia e exegese do Antigo Testamento. Volume 1. Tradução de "Equipe de colaboradores da Editora Cultura Cristã". São Paulo: Cultura Cristã, 2011.

Submetido em: 3-9-2020

Aceito em: 14-1-2021 